\title{
Correction to: Occurrence of genes associated with virulence in Escherichia coli isolates from chicken carcasses at different stages of processing at a slaughterhouse
}

João Juliano Pinheiro ${ }^{1}$. Luiz Eduardo de Souza Gazal ${ }^{2} \cdot$ Gabriella Oliveira de Araujo $^{1}$. Kelly Cristina Tagliari de Brito ${ }^{1}$ - Ivonete Fatima Tazzo ${ }^{3} \cdot$ Rafael Tonini Mesquita $^{1}$. Renata Katsuko Takayama Kobayashi ${ }^{2}$ - Luciana Kazue Otutumi ${ }^{4}$. José Matheus Beltrami ${ }^{5}$. Lissandra Souto Cavalli ${ }^{3}$. Benito Guimarães de Brito ${ }^{1}$

Published online: 17 September 2021

○) Sociedade Brasileira de Microbiologia 2021

Correction to: Braz J Microbiol https://doi.org/10.1007/s42770-021-00549-5

In this article the wrong figure appeared as Fig. 1.; the figure should have appeared as shown below.
Publisher's note Springer Nature remains neutral with regard to jurisdictional claims in published maps and institutional affiliations.
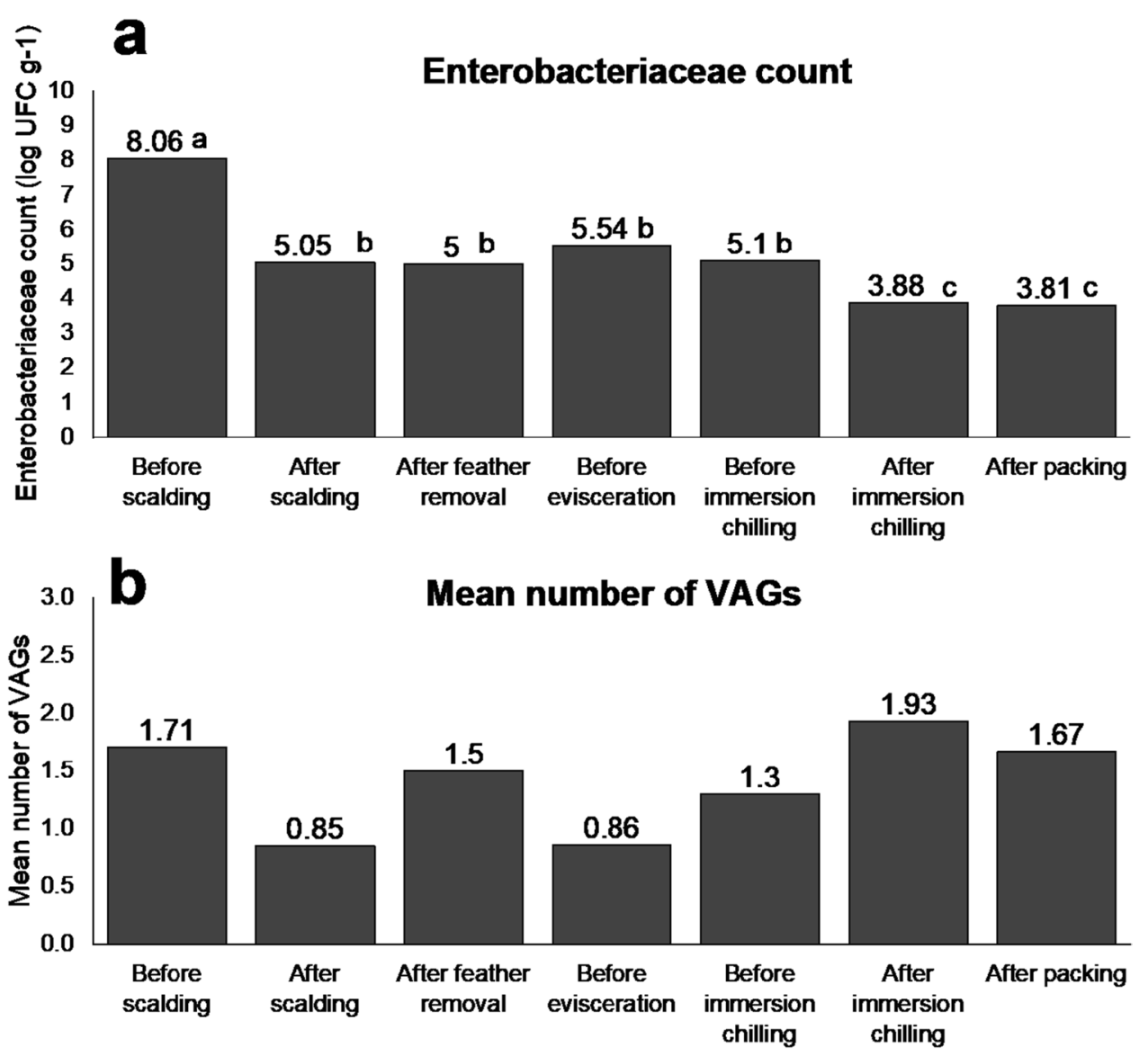
The original article can be found online at https://doi.org/10.1007/s42770-021-00549-5.

$\triangle$ Kelly Cristina Tagliari de Brito

kellybritofepagro@gmail.com

1 Laboratory of Avian Health and Technological Innovation, Institute for Veterinary Research Desidério Finamor (IPVDF), Postgraduate Program in Animal Health, Department of Agricultural Diagnosis and Research, Secretariat of AgricultureLivestock and Rural Development of Rio Grande Do Sul, Estrada do Conde, 6000, Sans Souci, Eldorado do Sul, RS 92990-000, Brazil

2 Bacteriology Laboratory, Department of Microbiology, Center for Biological Sciences, State University of Londrina, Rodovia Celso Garcia Cid, Km 380, S/N Campus Universitário, Londrina, PR 86057-970, Brazil

3 Department of Agricultural Diagnosis and Research, Secretariat of Agriculture, Livestock and Rural Development of Rio Grande do Sul, Rua Gonçalves Dias, 570, Menino Deus, Porto Alegre, RS 90130-060, Brazil

4 Postgraduate Program in Animal Science With Emphasis On Bioactive Products, Universidade Paranaense, Umuarama, PR, Brazil

5 Master in Animal Science, Universidade Paranaense, UNIPAR, Umuarama, PR, Brazil 